\title{
ANALISIS AKAD IJARAH MUNTAHIYA BITTAMLIK (IMBT) DALAM PERSPEKTIF HUKUM ISLAM DAN HUKUM POSITIF DI INDONESIA
}

\author{
Daffa Muhammad Dzubyan, Erina Azzahra, Melani Puspitasari \\ Prodi Hukum Ekonomi Syariah, Fakultas Syariah, Universitas Islam Bandung \\ Jl. Tamansari No.1 Bandung 40116 \\ dmuhammad217@gmail.com,erinaazzahra@gmail.com,melanipsptsrr@gmail.com
}

\begin{abstract}
Abstrak
Tujuan dalam penelitian ini untuk mengalisis perjanjian kontrak/akad Ijarah Muntahiya Bi Al-Tamlik (IMBT). Akad ini merupakan kombinasi dari akad ijarah (sewa menyewa) dengan akad murabahah (jual-beli). Akad ini menjadi terobosan baru dan memberikan banyak kemudahan bagi pelaku ekonomi, tetapi Akad IMBT masih diragukan oleh banyak pihak. Pada umumnya, mereka mempertanyakan bagaimana dasar hukum IMBT baik Hukum Islam dan Hukum Positif di Indonesia. Dalam perspektif Hukum Islam, IMBT dikatakan telah memenuhi prinsip-prinsip, pilar dan syarat-syarat dalam akad. Para pemikir ekonomi kontemporer banyak yang berpendapat bahwa hukum IMBT diperbolehkan. Bila dilihat dari sudut pandang Hukum Positif Indonesia, kontak/akad IMBT termasuk dalam perjanjian tidak bernama pada KUH Perdata (Pasal 1319) yang timbul dari prinsip kebebasan berkontrak (Pasal 1338) dan IMBT juga memenuhi persyaratan perjanjian yang sah (Pasal 1320) sebagai serta perjanjian elemen.
\end{abstract}

Kata Kunci: Ijarah Muntahiya Bi Al-Tamlik (IMBT), Hukum Islam, Hukum Positif.

\begin{abstract}
Abstact
The rapid development of the Islamic banking industry requires Islamic economists and Islamic banking industry players to be more innovative. One form of this challenge is the emergence of a new contract namely the contract agreement Ijarah Muntahiya Bi Al-Tamlik (IMBT). This contract is a combination of ijarah contract (rent) with murabahah (sale and purchase) contract. This contract is a new breakthrough and provides many facilities for economic actors, but the IMBT contract is still in doubt by many parties. In general, they questioned how the legal basis of IMBT both Islamic Law and Positive Law in Indonesia. In the perspective of Islamic Law, IMBT is said to have fulfilled the principles, pillars and conditions in the contract. Many contemporary economic thinkers argue that the IMBT law is permissible. When viewed from the standpoint of Indonesian Positive Law, the IMBT contact is included in an unnamed agreement in the Civil Code (Article 1319) arising from the principle of freedom of contract (Article 1338) and IMBT also fulfills the requirements of a legal agreement (Article 1320) as well as agreements element. The legal consequences arising from IMBT contract / contract agreements are their rights and obligations to do so.
\end{abstract}

Keywords: Ijarah Muntahiya Bi Al-Tamlik, Islamic Law and Positive Law.

Received: 2019-01-05 | Reviced: 2019-07-29 | Accepted: 2019-07-30

Diindeks : Sinta, DOAJ, Garuda, CrossRef, Google Scholar | DOI: https://doi.org/10.29313/amwaluna.v3i2.4304 
Daffa Muhammad Dzubyan, Erina Azzahra, Melani Puspitasari, Analisis Akad Ijarah Muntahiya Bittamlik (Imbt)

\section{PENDAHULUAN}

Bank sebagai lembaga yang bekerja berdasarkan kepercayaan masyarakat, memiliki peran dan posisi yang sangat strategis dalam pembangunan nasional. (Imaniyati， 2008， hal. 24) Semakin berkembangnya Perbankan Syariah di Indonesia menjadikan produk-produk yang ada di perbankan syariah juga ikut berkembang pesat. Tidak hanya mempertahankan bentuk akad yang sudah ada sejak zaman dulu, kini para cendekiawan serta praktisi yang bergelut di Perbankan Syariah juga mengembankan berbagai macam model bentuk akad baru. Berbagai model bentuk akad baru tersebut selain sebagai upaya untuk mengembangkan perbankan syariah juga sebagai bentuk pernyesuaian perbankan syariah terhadap kemajuan perkembangan zaman.

Salah satu bentuk akad baru dari lembaga keuangan syariah yang ada saat ini adalah akad pembiayaan "Ijarah Muntahiya Bi Al-Tamlik (IMBT)". IMBT merupakan kombinasi antara sewa menyewa (ijarah) dengan jual beli (murabahah) atau hibah di akhir masa sewa. (Karim, 2006, hal. 165) Hal ini dapat disimpulkan terdapat dua bentuk penggabungan akad (hybrid contract) sekaligus yaitu sewa menyewa dengan jual beli dan sewa menyewa dengan hibah. Penggabungan akad adalah kesepakatan dua pihak untuk melaksanakan suatu muamalah yang meliputi dua akad atau lebih. Sehingga akibat hukum dari akad gabungan tersebut yaitu semua hak dan kewajiban yang ditimbulkannya dianggap satu kesatuan yang tidak dapat di pisah-pisahkan, yang sama kedudukannya dengan akibat-akibat hukum dari satu akad. (Karim, 2006) Salah satu parameter untuk menilai suatu produk Perbankan Syariah apakah memenuhi Prinsip Syariah atau tidak adalah dengan memperhatikan akad dan berbagai ketentuannya yang digunakan dalam produk tersebut.Metode yang digunakan dalam penelitian ini adalah kualitatif.

Meski model akad baru tersebut merupakan sebuah langkah yang inovatif, namun hal tersebut masih menimbulkan polemik. Pasalnya, dari sisi penggabungan akadnya sendiri di kalangan para ulama Imam Mazhab masih menjadi khilafiah (perbedaan), belum lagi nanti di tinjau dari hukum positif yang ada di Indonesia, apakah sudah sesuai atau justru malah tumpang tindih. Berangkat dari permasalahan itulah sangat diperlukan kajian yang komprehensif dan holistic mengenai akad gabungan baik secara hukum syariat dan hukum positif yang ada di Indonesia. 
II. PEMBAHASAN

\section{Pengertian Akad Ijarah Muntahiya Bi} Al-Tamlik

Ijarah Muntahiya Bi Al-Tamlik (financial leasing with purchase option) atau akad sewa menyewa yang berakhir dengan kepemilikan ini pada dasarnya tidak terdapat dikalangan fuqaha terdahulu. Untuk mencari definisinya, maka kita harus mengurai kata yang terkandung di dalamnya lalu (secara etimologi) lalu baru kita dapat menyimpulkan definisi secara keseluruhan (secara terminologi). Dari susunan katanya, Ijarah Muntahiya Bi AlTamlik memiliki susunan kata yang terdiri dari "Al-Ijarah" dan "At-Tamlik".

Al-Ijarah dalam istilah para ulama ialah suatu akad yang mendatangkan manfaat yang jelas lagi mubah berupa suatu dzat yang ditentukan ataupun yang disifati dalam sebuah tanggungan, atau akad terhadap perkerjaan yang jelas dengan imbalan yang jelas serta tempo waktu yang jelas. (Antonio, 2001, hal. 117)

Sedangkan At-Tamlik secara bahasa bermakna menjadikan orang lain memiliki sesuatu. Adapun menurut istilah ia tidak keluar dari maknanya secara bahasa. Dan At-Tamlik bisa berupa kepemilikan terhadap benda, kepemilikan terhadap manfaat, bisa dengan ganti atau tidak. Jika kepemilikan terhadap sesuatu terjadi dengan adanya ganti maka ini adalah jual beli. Jika kepemilikan terhadap suatu manfaat dengan adanya ganti maka disebut persewaan. Adapun menurut Fahd alHasun dalam bukunya "Al-Ijarah alMuntahiya bi Al-Tamlik fi Al-fiqh Al-Islam" mendefinisikan Ijarah Muntahiya bi AlTamlik adalah kepemilikan manfaat suatu barang dalam jangka waktu tertentu disertai pemindahan kepemilikan barang tersebut kepada penyewa dengan pengganti tertentu. (Al-Hasun, 2005, hal. 17) Sedangkan menurut Habsi Ramli, Ijarah Muntahiya bi Al-Tamlik adalah akad sewa menyewa antara pemilik objek sewa dan penyewa untuk mendapatkan imbalan atas objek sewa yang disewakannya dengan opsi perpindahan hak milik objek sewa pada saat tetentu sesuai dengan akad sewa. (Ramli, 2005, hal. 65)

Sementara itu dalam Undangundang juga mendefinisikan Ijarah Muntahiya bi Al-Tamlik berdasarkan Pasal 19 ayat (1) huruf $f$ UU Perbankan Syariah No.21 Tahun 2008, yang dimaksud dengan akad Ijarah Muntahiya bi Al-Tamlik adalah akad penyediaan dana dalam rangka memindahkan hak guna atau manfaat dari suatu barang atau jasa berdasarkan transaksi sewa dengan opsi pemindahan kepemilikan barang. (Neneng Nurhasanah, 2017, hal. 384) Pembiayaan 
Daffa Muhammad Dzubyan, Erina Azzahra, Melani Puspitasari, Analisis Akad Ijarah Muntahiya Bittamlik (Imbt)

Ijarah Muntahiya bi Al-Tamlik merupakan salah satu bentuk kegiatan usaha bank syariah atau Lembaga Keuangan Syariah yang dilaksanakan berdasarkan prinsip syariah.

Selain dari Undang-undang Perbankan syariah, Fatwa DSN-MUI pun mendefinisikan akad Ijarah Muntahiya bi Al-Tamlik berdasarkan fatwa DSN-MUI No. 27/DSN-MUI/III/2002 tentang $A l$ Ijarah Al-Muntahiya Bi Al-Tamlik, yang dimaksud dengan sewa beli (Al-Ijarah Muntahiya Bi Al-Tamlik/IMBT), yaitu perjanjian sewa menyewa yang disertai opsi pemindahan hak milik atas benda yang disewa, kepada penyewa, setelah selesai masa sewa.

Berdasarkan ketentuan-ketentuan tersebut di atas dapat disimpulkan bahwa:

\section{Ijarah Muntahiya Bi Al-Tamlik} adalah perjanjian sewa-menyewa antara bank sebegai pemberi sewa dan nasabah sebagai penyewa atas suatu barang yang menjadi objek sewa dalam waktu tertentu melalui pembayaran sewa oleh nasabah kepada bank, yang mengikat bank untuk mengalihkan kepemilikan objek sewa kepada penyewa setelah selesai masa sewa.
2. Dalam transaksi pembiayaan berdasarkan Ijarah Muntahiya Bittamlik tidak dimungkinkan barang yang dibiayai dibalik nama atas nama nasabah sejak awal sebelum sewa berakhir.

3. Resiko yang dihadapi bank syariah apabila pelasanaan pembiayaan dengan akad Ijarah Muntahiya Bittamlik bertentangan dengan hukum dan prinsip syariah adalah pembatalan Ijarah Muntahiya Bittamlik tersebut demi hukum.

\section{Dasar Hukum Ijarah}

Ijarah sebagai suatu transaksi yang sifatnya saling tolong menolong mempunyai landasan yang kuat dalam AlQur'an dan Hadits. Adapun yang menjadi dasar hukum Ijarah adalah: (Tim Penulis Dewan Syari'ah Nasional (DSN) MUI, 2003, hal. 54)

a. Al-Qur'an

- Q.S al-Zukhruf [43]:32 "Apakah mereka yang membagibagikan rahmat Tuhanmu? Kami telah menentukan antara mereka penghidupan mereka dalam kehidupan dunia, dan kami telah meninggikan sebagian mereka atas sebagian yang lain beberapa derajat, agar sebagian mereka dapat 
mempergunakan sebagian yang lain. Dan rahmat Tuhanmu lebih baik daripada apa yang mereka kumpulkan"

- Q.S Al-Baqarah[2]:233

“... dan jika kalian ingin anakmu disusukan oleh orang lain, tidak dosa bagimu apabila kalian memberikan pembayaran menurut yang patut. Bertakwalah kepada Allah; dan ketahuilah Allah Maha Melihat apa yang kalian kerjakan.”

- Q.S al-Qashash [28]: 26

"Salah seorang dari kedua wanita itu berkata: Hai ayahku, ambilah ia sebagai orang yang bekerja pada (kita), karena sesungguhnya orang yang paling baik yang kamu ambil untuk bekerja (pada kita) adalah orang kuat lagi dapat dipercaya."

b. Hadits

- HR. Ibnu Majah

"Dari Abdullah bin Umar bahwa Rasulallah saw bersabda: Berikanlah upah kepada pekerja sebelum keringatnya kering".

- HR. Abdur Razaq

"Dari Abu Hurairah bahwa Rasulallah saw bersabda: Apabila kamu mengangkat pekerja maka beritahukanlah upahnya".

- HR. Al-Darimi
"Dari Sa'ad bin Abi Waqqash, dia berkata: Kami pernah menyewakan tanah pada masa Rasulallah saw dengan (bayaran) hasil pertaniannya, maka Rasulallah saw melarang kami melakukan hal tersebut dan mengizinkan kami menyewakannya dengan emas atau perak".

- HR. Tirmidzi

"Dari Amr bin Auf dari ayahnya dari kakeknya bahwa Rasulallah saw bersabda: Perdamaian dapat dilakukan diantara kaum muslimin kecuali perdamaian yang mengharamkan yang halal atau menghalalkan yang haram; dan kaum muslimin terikat dengan syarat-syarat mereka kecuali syarat yang mengharamkan yang halal atau menghalalkan yang haram”.

c. Ijma 'ulama tentang kebolehan melakuakn akad sewa menyewa.

d. Kaidah Fikih

- "Pada dasarnya semua bentuk muamalah boleh dilakukan kecuali ada dalil yang mengharamkannya"

- "Menghindarkan mafsadat (kerusakan/bahaya) harus didahulukan atas mendatangkan kemaslahatan"

e. Hukum Positif Indonesia 
Daffa Muhammad Dzubyan, Erina Azzahra, Melani Puspitasari, Analisis Akad Ijarah Muntahiya Bittamlik (Imbt)

- Undang-Undang Nomor 21 Tahun 2008 Tentang Perbankan Syariah Pasal 19 Ayat 1

Yang dimaksud dengan "Akad Ijarah" adalah akad penyediaan dana dalam rangka memindahkan hak guna atau manfaat dari suatu barang atau jasa berdasarkan transaksi sewa, tanpa diikuti dengan pemindahan kepemilikan barang itu sendiri

Yang dimaksud dengan "Akad Ijarah Muntahiya Bittamlik” adalah akad penyediaan dana dalam rangka memindahkan hak guna atau manfaat dari suatu barang atau jasa berdasarkan transaksi sewa dengan opsi pemindahan kepemilikan barang. (Neneng Nurhasanah, 2017, hal. 384)

\section{Rukun dan Syarat Akad Ijarah Muntahiya Bittamlik}

Adapun Rukun dan Syarat Akad Ijarah Muntahiya Bittamlik adalah:

\section{Rukun}

a. Penyewa (musta'jir) yaitu pihak yang menyewa objek sewa. Dalam perbankan, penyewa adalah nasabah. b. Pemilik barang (mua'ajjir) yaitu pemilik barang yang digunakan sebagai objek sewa.

c. Barang/objek sewa (ma'jur) adalah barang yang disewakan.

d. Harga sewa/manfaat sewa (ujrah) adalah manfaat atau imbalan yang diterima oleh mu'ajjir.

e. Ijab Kabul, adalah serah terima barang.

Syarat

a. Kerelaan dari pihak yang melaksanakan akad.

b. Ma'jur memiliki manfaat dan manfaatnya dibenarkan dalam islam, dapat dinilai atau diperhitungkan, dan manfaat atas transaksi ijarah muntahiya bittamlik harus diberikan oleh musta'jir kepada mua'ajjir. (Ismail, 2011, hal. 164)

Disamping ketentuan yang berlaku untuk ijarah, untuk kegiatan penyaluran dana dalam bentuk pembiayaan atas dasar ijarah muntahiya bi al-tamlik berlaku pula persyaratan paling kurang sebagai berikut: (Ansori, 2009, hal. 128-129)

a. Bank sebagai pemilik objek sewa bertindak sebagai pemberi janji (wa'ad) untuk memberikan opesi pengalihan kepemilikan dan/atau 
hak penguasaan objek sewa kepada nasabah penyewa sesuai kesepakatan;

b. Bank hanya dapat memberi janji (wa'ad) untuk mengalihkan kepemilikan dan/atau hak penguasaan objek sewa setelah objek sewa secara prinsip dimiliki oleh Bank;

c. Bank dan nasabah harus menuangkan kesepakatan adanya opsi pengalihan kepemilikan dan/atau hak penguasaan objek sewa dalam bentuk tertulis;

d. Pelaksanaan pengalihan kepemilikan dan/atau hak penguasaan objek sewa dapat dilakukan setelah masa sewa disepakati setelah masa sewa disepakati setelah oleh Bank dan nasabah penyewa; dan

e. Dalam hal nasabah penyewa mengambil opsi pengalihan kepemilikan dan/atau hak penguasaan objek sewa, maka bank wajib mengalihkan kepemilikan dan/atau hak penguasaan objek sewa kepada nasabah yang dilakukan pada saat tertentu dalam periode atau akhir periode pembiayaan atas dasar akad ijarah muntahiya bi al-tamlik.

\section{Bentuk-bentuk Ijarah Muntahiya Bittamlik}

Menurut Imam Mustofa, ijarah muntahiya bi al-tamlik memiliki lima bentuk, yaitu: (Mustofa, 2016, hal. 115118)

- Pertama, akad ijarah yang sejak awal akad dimaksudkan untuk memindahkan kepemilikan barang sewa kepada pihak penyewa. Penyewa menyewa suatu barang dengan pembayaran sewa secara angsur dalam kurun waktu tertentu dengan jumlah tertentu pada saat angsuran terakhir barang sewaan berpindah kepemilikan kepada pihak penyewa. Dalam hal ini tidak ada akad baru untuk memindahkan hak barang tersebut setelah sewa lunas.

- Kedua, akad ijarah dari awal dimaksudkan hanya untuk sewa, tetapi si penyewa diberi hak untuk memiliki barang sewaan dengan memberikan uang pengganti dalam jumlah tertentu. Dalam hal ini tidak ada perjanjian yang mengikat di antara keduanya untuk memindahkan hak barang dengan cara jual-beli karena akad yang dibuat adalah sewa murni. Jadi ada 
Daffa Muhammad Dzubyan, Erina Azzahra, Melani Puspitasari, Analisis Akad Ijarah Muntahiya Bittamlik (Imbt)

dua akad yang berbeda dan tidak dalam waktu bersamaan, yaitu akad ijarah atau sewa sampai waktu yang telah ditentukan, kemudian setelah sewa lunas/selesai, maka ada akad baru, yaitu jual-beli.

- Ketiga, akad ijarah dimaksudkan untuk sewa suatu barang, yaitu saat akad pihak penyewa dan pemberi sewa membuat perjanjian yang mengikat untuk melakukan akad jual-beli barang objek sewa. Pemberi sewa akan menjual barang yang disewa kepada penyewa dengan sejumlah harga tertentu setelah angsuran sewa lunas. Jadi ada perjanjian antara kedua belah pihak bahwa akan ada akad jual-beli di akhir masa sewa.

- Keempat, akad ijarah dimaksud untuk sewa suatu barang, yaitu pada saat akad pihak penyewa dan pemberi sewa membuat perjanjian yang mengikat untuk melakukan hibah barang objek sewa. Pemberi sewa akan menghibahkan barang yang disewa kepada penyewa.

- Kelima, akad ijarah dimaksudkan untuk sewa suatu barang dalam jangka waktu tertentu dengan pembayaran dalam jumlah tertentu. Pada saat akad, pihak penyewa dan pemberi sewa membuat perjanjian yang mengikat untuk memberikan hak tiga opsi kepada pihak penyewa. Opsi pertama pihak penyewa menjadi pemilik dengan pembayaran sejumlah uang yang telah diangsurkan bersamaan dengan angsuran uang sewa. Pelaksanaan perjanjian pembayaran ini dilakukan sejak awal, pembayaran uang pengganti perpindahan kepemilikan juga dilakukan sejak pembayaran angsuran pertama. Opsi kedua memperpanjang masa sewa. Opsi ketiga, pihak penyewa mengembalikan barang sewaan kepada pemberi sewa.

\section{Implementasi Ijarah Muntahiya Bittamlik Di Lembaga Keuangan Syariah}

Akad ijarah diaplikasikan dalam perbankan syariah pada pembiayaan Ijarah dan IMBT (Ijarah Muntahiya Bittamlik). Pada umumnya bank syariah lebih banyak menggunakan IMBT karena lebih sederhana dalam pembukuannya. Selain itu, bank tidak direpotkan untuk mengurus 
pemeliharaan aset, baik pada saat leasing maupun sesudahnya. Ijarah muntahiya Bittamlik (financial leasing with option purchase option) merupakan akad sewamenyewa yang berakhir dengan kepemilikan. Akad ini merupakan rangkaian dua buah akad, yaitu akad ijarah dan akad bai'.

Sementara itu, operasional IMBT secara khusus didasarkan pada fatwa DSNMUI No. 27/DSN-MUI/III/2002 tentang ijarah muntahiya bi al-tamlik. Dalam pelaksanaan akad IMBT ada ketentuan yang harus dipenuhi, yakni ketentuan yang bersifat umum dan ketentuan yang bersifat khusus, ketentuan yang bersufat umum, yaitu:

a. Rukun dan syarat yang berlaku dalam akad ijarah berlaku pula akad IMBT;

b. Perjanjian untuk melakukan akad IMBT harus disepakati ketika akad ijarah ditandatangani;

c. Hak dan kewajiban setiap pihak dijelaskan dalam akad.

Adapun yang bersifat khusus, yaitu:

a. Pihak yang melakukan IMBT harus melakukan akad ijarah terlebih dahulu. Akad pemindahan kepemilikan, baik dengan jual-beli maupun hibah hanya dapat dilakukan setelah masa ijarah selesai;

b. Janji pemindahan kepemilikan yang disepakati di awal akad ijarah adalah janji (wa'ad) yang hukumnya tidak mengikat. Apabila wa'ad ingin dilaksanakan, maka harus ada akad pemindahan kepemilikan yang dilakukan setelah masa ijarah selesai.

Dalam Kompilasi Hukum Ekonomi Syariah (KHES), ketentuan mengenai ijarah muntahiya bi al-tamlik diatur dalam bab kesembilan Pasal 332-329. Rukun dan syarat dalam ijarah dapat diterapkan dalam pelaksanaan IMBT. Dalam akad ini, perjanjian antara mu'jir (pihak yang menyewakan) dengan musta'jir (pihak penyewa) diakhiri dengan pembelian ma'jur (objek ijarah) oleh pihak penyewa. Kemudian, ijarah muntahiya bi al-tamlik harus dinyatakan secara eksplisit dalam akad. Akad pemindahan kepemilikan hanya dapat dilakukan setelah masa sewa berakhir. (Adam, 2017, hal. 221)

Aplikasi IMBT dalam perbankan syariah berupa: Pertama, pembiayaan invsetasi; seperti untuk pembiayaan barangbarang modal, sepeti mesin-mesin; Kedua, pembiayaan konsumer, seperti untuk pembelian mobil, rumah dan sebagainya. 
Daffa Muhammad Dzubyan, Erina Azzahra, Melani Puspitasari, Analisis Akad Ijarah Muntahiya Bittamlik (Imbt)

Pembiayaan ijarah dan IMBT di perbankan syariah memiliki persamaan perlakuan dengan pembiayaan murabahah. Sampai saat ini, mayoritas produk pembiayaan bank syariah masih terfokus pada produk-produk murabahah (jual-beli disertai keuntungan). Kesamaan keduanya, bahwa pembiayaan tersebut termasuk dalam kategori natural certainty contract, dan pada dasarnya adalah kontrak jual-beli. Perbedaan kedua jenis pembiayaan (ijarah/IMBT dengan murabahah) hanyalah objek transaksi yang diperjualbelikan tersebut. Dalam pembiayaan murabahah, objek transaksi adalah barang seperti rumah dan mobil, sedangkan dalam pembiayaan ijarah, objek transaksinya adalah jasa, baik manfaat atas barang maupun manfaat atas tenaga kerja. Dengan pembiayaan murabahah, bank syariah hanya dapat melayani kebutuhan nasabah untuk memiliki barang, sedangkan nasabah membutuhkan jasa tidak dilayani. Dengan skim ijarah, bank syariah dapat pula melayani nasabah yang hanya membutuhkan jasa.

Ijarah muntahiya bi al-tamlik dalam bank syariah umumnya melalui tahapantahapan sebagai berikut: (Mustofa, 2016, hal. 124)

1. Nasabah menjelaskan kepada bank, bahwa suatu saat di tengah atau di akhir periode ijarah ia ingin memiliki;

2. Setelah melakukan penelitian, bank setuju akan menyewakan aset itu kepada nasabah;

3. Apabila bank setuju, bank terlebih dahulu memiliki aset tersebut;

4. Bank membeli atau menyewa aset yang dibutuhkan nasabah;

5. Bank membuat perjanjian ijarah dengan nasabah untuk jangka waktu tertentu dan menyerahkan aset itu untuk dimanfaatkan;

6. Nasabah membayar sewa setiap bulan yang jumlahnya sesuai dengan kesepakatan;

7. Bank melakukan penyusutan terhadap aset; biaya penyusutan dibebankan kepada laporan laba/rugi;

8. Di tengah atau diakhir masa sewa, bank dan nasabag dapat melakukan pemindahan kepemilikan aset tersebut secara jual-beli cicilan;

9. Jika pemindahan kepemilikan di akhir masa sewa, akadnya dilakukan secara hibah.

Secara konseptual IMBT hampir sama dengan leasing, bahwa leasing merupakan bentuk pembiayaan dalam bentuk penyediaan barang-barang modal untuk digunakan oleh perusahaan tertentu, 
berdasarkan pembayaran secara berkala, disertai dengan hak pilih/opsi perusahaan tersebut untuk membeli barang modal yang bersangkutan atau memperpenjang jangka waktu leasing berdasarkan nilai sisa yang telah disepakati bersama. Dari aspek pemindahan kepemilikan, dalam leasing dikenal dua jenis, yaitu operating lease dan financial lease. Dalam operating lease, tidak terjadi pemindahan kepemilikan aset, baik di awal maupun di akhir periode sewa. Dalam hal ini, operating lease sama seperti ijarah. Ijarah merupakan akad yang mengatur pemanfaatan hak guna tanpa terjadi pemindahan kepemilikan. Dalam financial lease, di akhir periode sewa si penyewa diberikan pilihan untuk membeli atau tidak membeli barang yang disewa. Namun, pada praktiknya, dalam financial lease sudah tidak ada opsi lagi untuk membeli atau tidak membeli karena pilihan itu sudah ditentukan di awal periode.

Namun ijarah muntahiya bi al-tamlik memiliki perbedaan dengan leasing konvensional, seperti tergambar pada tabel berikut ini:

\section{Perbedaan ijarah muntahiya bi al-tamlik} dengan leasing: (Adam, 2017, hal. 223)

\begin{tabular}{|cc|cc|}
\hline \multicolumn{2}{|c|}{ IMB T } & \multicolumn{2}{c|}{ Leasing } \\
\hline Aset & selama masa & Aset & langsing \\
\hline
\end{tabular}

\begin{tabular}{|c|c|}
\hline $\begin{array}{l}\text { sewa adalah milik } \\
\text { bank/mu'jir }\end{array}$ & $\begin{array}{l}\text { dicacatkan atas } \\
\text { nama nasabah. }\end{array}$ \\
\hline $\begin{array}{l}\text { Perjanjian } \\
\text { menggunakan akad } \\
\text { ijarah dan wa'ad } \\
\text { untuk jual-beli atau } \\
\text { hibah yang akan } \\
\text { ditandatangani } \\
\text { setelah ijarah } \\
\text { berakhir (jika } \\
\text { nasabah } \\
\text { menghendaki). }\end{array}$ & $\begin{array}{l}\text { Sewa dan jual-beli } \\
\text { menjadi satu } \\
\text { kesatuan dalam satu } \\
\text { perjanjian. }\end{array}$ \\
\hline $\begin{array}{l}\text { Perpindahan } \\
\text { kepemilikan } \\
\text { menggunakan jual- } \\
\text { beli dan hibah. } \\
\text { Perpindahan } \\
\text { kepemilikan } \\
\text { dilaksanakan setelah } \\
\text { masa ijarah selesai }\end{array}$ & $\begin{array}{l}\text { Perpindahan } \\
\text { kepemilikan } \\
\text { menggunakan jual- } \\
\text { beli. Perpindahan } \\
\text { kepemilikan diakui } \\
\text { setelah seluruh } \\
\text { pembayaran sewa } \\
\text { diselesaikan. }\end{array}$ \\
\hline
\end{tabular}

\section{Analisis Akad Ijarah Muntahiya Bittamlik}

Akad Ijarah Muntahiya Bittamlik dapat ditinjau dari beberapa aspek:

\section{a. Analisis Akad Ijarah Muntahiya Bittamlik dari Rukun Akad}

Rukun adalah unsur yang mutlak harus ada dalam sesuatu hal, peristiwa atau tidndakan. Pertama, adanya Shighat. Akad 
Daffa Muhammad Dzubyan, Erina Azzahra, Melani Puspitasari, Analisis Akad Ijarah Muntahiya Bittamlik (Imbt)

IMBT terdapat dua bentuk akad yaitu akad Ijarah yang diakhir dengan janji akad jualbeli dan akad Ijarah yang diakhiri dengan janji hibah. Pihak yang menyewakan berjanji (wa'ad) kepada penyewa untuk memindahkan kepemilikan objek setelah masa sewa berakhir yang dinyatakan dalam akad IMBT. Karenanya dalam akad IMBT terdapat dua akad yang berbeda, yaitu akad Ijarah, dan pada akhir masa ijarah dibuat suatu akad pengalihan hak atas barang yang disewakan. (Suswinarno, 2011, hal. 108) Sehingga ijab dan qabul antara Bank Syariah dan nasabah dapat diketahui dengan jelas cara pemindahan kepemilikan objek pada awal kesepakatan. Kedua, pelaksana akad (Al-Aqid). Pihak-pihak yang melakukan akad IMBT yaitu Musta'jir (Penyewa) adalah pihak yang menyewa aset yaitu Nasabah (debitur) dan Mu'jir (Pemilik) pihak pemilik yang menyewakan aset yaitu Bank Syariah (kreditur). Ketiga, objek akad (AlMa'aqud). Objek akad dalam akad IMBT yaitu ma'jur (aset yang disewakan) yaitu manfaat dan jasa pada suatu barang dan ujrah (harga sewa) yaitu harga yang disepakati oleh para pihak dalam akad IMBT.

Pada umumnya objek akad dapat dianggap sah apabila memenuhi syarat, yaitu telah ada pada waktu akad diadakan, dibenarkan oleh syara', dapat ditentukan dan diketahui dan objek diserahkan pada waktu akad terjadi. Walaupun demikian, beberapa syarat tersebut dapat disimpangi yaitu objek akad telah ada pada waktu akad IMBT diadakan dan syarat bahwa objek akad IMBT diserahkan pada waktu akad IMBT terjadi. Pengecualian ini didasarkan pada prinsip istihsan (Syarifuddin, 2009, hal. 319) yaitu dalil yang terkuat menunjukan bahwa hukum islam adalah suatu hukum yang berkembang dalam masyarakat untuk menjaga dan memenuhi kebutuhan manusia dan tidak bertentangan dengan syara'.

\section{b. Analisis Akad Ijarah Muntahiya Bittamlik ditinjau dari Syarat-syarat Akad}

Syarat adanya akad, yaitu sesuatu yang mesti ada agar keberadaan suatu akad diakui syara'. Makna akad secara syar'i yaitu hibungan antara ijab dan qabul dengan cara yang dibolehkan oleh syariat yang mempunyai pengaruh secara langsung. (Azzam, 2010, hal. 17) Syarat adanya akad harus memenuhi syarat umum yaitu terpenuhinya rukun akad dan syarat khusus. Yaitu syarat tambahan seperti adanya saksi. Akad IMBT yang dibuat secara notariil maupun dibawah tangan terdapat minimal dua sanksi yang hadir. 
Sehingga dengan terpenuhinya syarat umum dan syarat khusus maka telah adanya akad IMBT.

Syarat sahnya akad adalah tidak terdapatnya lima hal perusak sahnya akad yaitu kertidakjelasan jenis yang menyebabkan pertengkaran, adanya paksaan, membatasi kepemilikan terhadap suatu barang, terdapat unsur tipuan, terdapat bahaya dalam pelaksanaan akad. Agar terhindar dari lima hal perusak akad IMBT diatur dalam Fatwa DSN Nomor: 27/DSN-MUI/III/2002 tentang al-Ijarah almuntahiya bi al-tambik, PBI Nomor: 7/46/PBI/2005 dan Kompilasi Hukum Ekonomi Syariah (KHES).

Syarat berlakunya akad. Untuk kelangsungan akad diperlukan dua syarat adanya kepemilikan atau kekuasaan dan di dalam objek akad tidak ada hak orang lain. Bank Syariah merupakan pemilik objek akad IMBT sebagai pihak yang menyewakan barang kepada nasabah. Baik Bank Syariah dan nasabah merupakan orang yang mampu melaksanakan akad IMBT yaitu cakap dalam perbuatan hukum. Selain itu, mengenai objek akad yang disewakan kepada musta 'jir merupakan hak milik dari pihak mu'ajjir selama masa sewa. Setelah masa sewa berakhir terjadi perpindahan hak milik kepada nasabag dengan cara jual beli atau hibah.
Syarat adanya kekuatan hukum adalah persyaratan yang ditetapkan oleh syara' berkenaan dengan kepastian sebuah akad. Akad sendiri sesungguhnya sebuah ilzam (kepastian). Jika sebuah akad belum bisa dipastikan berlakunya seperti ada unsur tertentu yang menimbulkan hak khiyar, maka akad ini dalam kondisi ghairu lazim (belum pasti), karena masing-masing pihak berhak menfasakhkan akad atau tetap melangsungkannya. (Masadi, 2002, hal. 103)

Berdasarkan Fatwa DSN Nomor 27/DSN-MUI/III/2002 pada bagian kedua mengatur ketentuan khusus mengenai janji pemindahan hak milik yang sifatnya tidak mengikat, hal ini mengundang penafsiran ganda.

1. Ketidakterikatan itu bisa dimaknai tidak terikat untuk membuat janji pemindahan hak milik, ketentuan ini tidak sejalan dengan maksud diakadkannya IMBT

2. Dapat dimaknai tidak terikat untuk melaksanakan janji yang sudah disepakati dalam akad IMBT. Ketentuan seperti ini tidak lazim dalam hukum perjanjian yang dibuat dipandang sebagai undangundang yang selalu mengikat dan harus ditaati. 
Daffa Muhammad Dzubyan, Erina Azzahra, Melani Puspitasari, Analisis Akad Ijarah Muntahiya Bittamlik (Imbt)

Jika suatu akad boleh tidak dilaksanakan, maka akad IMBT itu tidak ada gunanya dan akan kehilangan makna dan tujuannya, bahkan dapat menimbulkan kezaliman. Penyewa yang sejak semula berniat untuk memiliki benda dan telah melunasi seluruh angsurannya, sudah pasti merasa dirugikan jika ternyata penyewa tidak dapat memiliki barang karena pemberi sewa tidak mau menghibahkannya dengan alasan janji itu tidak mengikat. Pelaksanaan akad IMBT seperti ini tidak sesuai dengan tujuan dibuatnya akad IMBT yakni diakhiri dengan pemindahan hak milik. Selain itu, Pasal 324 ayat (2) KHES menyebutkan bahwa "Akad pemindahan kepemilikan hanya dapat dilakukan setelah masa Ijarah Muntahiya Bittamlik berakhir". Ketentuan tersebut dapat diartikan bahwa pemindahan kepemilikan melalui akad jual beli merupakan akad tersendiri yang bukan merupakan satu kesatuan dari akad IMBT. Sehingga dapat disimpulkan dalam akad IMBT tidak ada pemindahan kepemilikan, artinya tujuan dari akad IMBT tidak tercapai. Padahal pada hakekatnya akad IMBT berakhir ketika adanya pemindahan kepemilikan.

\section{c. Analisis Akad Ijarah Muntahiya} Bittamlik ditinjau dari Jenis Perjanjian dalam Hukum Positif di Indonesia
Pasal 1319 KUHPerdata menyebutkan dua kelompok perjanjian, yaitu perjanjian yang oleh oleh undang-undang diberikan suatu nama khusus disebut dengan perjanjian bernama (benoemde atau nominaatcontracten) dan perjanjian yang dalam undang-undang tidak dikenal dengan suatu nama tertentu disebut dengan perjanjian tak bernama (onbenoemde atau innominaatcontracten). (Hatta, 2000, hal. 125-125) Lahirnya perjanjian tak bernama adalah berdasarkan asas kebebasan berkontrak atau partij otonomi tang berlaku di dalam hukum perjanjian. (Prodjodikoro, 1973, hal. 19) Salah satunya yaitu perjanjian IMBT. Perjanjian IMBT memang tidak dijelaskan secara jelas dalam KUHPerdata, sehingga perjanjian ini dikategorikan sebagai perjanjian tidak bernama. Walaupun demikian, perjanjian tidak bernama tetap berlandaskan ketentuan KUHPerdata, sebagaimana diatur dalam pasal 1319 yang berbunyi:

"Semua perjanjian, baik yang mempunyai nama khusus, maupun yang tidak dikenal dengan suatu nama tertentu, tunduk pada peraturan-peraturan umum, yang termuat di dalam bab ini dan bab yang lalu."

Pasal ini menyatakan bahwa perjanjian apa saja, baik yang diatur dalam buku KUHPerdata Buku III Bab V sampai dengan Bab XVIII dan yang terdapat di 
luar Buku III KUHPerdata tunduk pada ketentuan-ketentuan umum dari KUHPerdata Buku III dan Buku II. Sehingga akad IMBT walaupun termasuk kategori perjanjian tidak bernama tetap harus tunduk pada ketentuan KUHPerdata.

\section{SIMPULAN}

\section{Akad Ijarah Muntahiya Bittamlik} (IMBT) merupakan akad baru yang menggabungkan antara dua akad dalam satu transaksi. Dalam perspektif hukum Islam IMBT telah memenuhi asas-asas, rukun dan tiga syarat akad. Sedangkan syarat yang tidak terpenuhi yaitu syarat adanya kekuatan hukum karena pada Fatwa DSN Nomor: 27/DSN-MUI/III/2002 terdapat ketentuan yang menimbulkan pernafsiran ganda pada angka 2 bagian kedua yang mengatur ketentuan khusus dan Pasal 324 ayat (2) pada Kompilasi Hukum Ekonomi Syariah. Para pakar ekonomi Islam kontemporer berpendapat bahwa hukum akad IMBT adalah mubah (boleh). Sementara itu IMBT jika ditinjau dari perspektif hukum positif (KUHPerdata), IMBT merupakan perjanjian tidak bernama (Pasal 1319) yang timbul dari akad kebebasan berkontrak (Pasal 1338) dan IMBT juga telah memenuhi syarat-syarat sah dari perjanjian (Pasal 1320) serta unsurunsur perjanjian. Sedangkan akibat hukum yang ditimbulkan dari akad perjanjian
IMBT adalah adanya hak dan kewajiban bagi mereka yang melakukannya.

\section{DAFTAR PUSTAKA}

Adam, P. (2017). Akad dan Produk Bank Syariah. Bandung: PT. Refika Aditama.

Al-Hasun, F. b. (2005). Al-Ijarah AlMuntahiya Bi Al-Tamlik fi Al-Fiqh Al-Islam. Maktabah Misyikah AlIslamiyyah.

Ansori, A. G. (2009). Perbankan Syariah di Indonesia. Yogyakarta: Universitas Gajah Mada.

Antonio, M. S. (2001). Bank Syariah: Dari Teori ke Praktik. Jakarta: Gema Inzani dan Tazkia Cendekia.

Azzam, A. A. (2010). Fiqh Muamalat SIstem Transaksi dalam Fiqh Islam. Jakarta: Amzah.

Hatta, S. G. (2000). Beli Sewa sebagai Perjanjian Tak Bernama: Pandangan masyarakat dan Sikap Mahkamah Agung Indonesia. Bandung: Alumni.

Imaniyati, N. S. (2008). Hukum Perbankan. Bandung: Fakultas Hukum Unisba.

Ismail. (2011). Perbankan Syariah. Jakarta: Kencana.

Karim, A. A. (2006). Bank Islam: Analisis

Fiqh dan keuangan. Jakarta: RajaGrafindo Persada.

Masadi, G. A. (2002). Fikih Muamalah Kontekstual. Jakarta: RajaGrafindo Persada. 
Daffa Muhammad Dzubyan, Erina Azzahra, Melani Puspitasari, Analisis Akad Ijarah Muntahiya Bittamlik (Imbt)

Mustofa, I. (2016). Fikih Muamalah

Kontemporer. Jakarta: PT Rajawali

Grafindo Persada.

Neneng Nurhasanah, P. A. (2017). Hukum

Perbankan Syariah: Konsep dan

Regulasi. Jakarta: Sinar Grafika.

Prodjodikoro, W. (1973). Hukum perdata

tentang Persetujuan-Persetujuan

tertentu. Bandung: Alumni.

Ramli, H. (2005). Teori Dasar Akuntansi Syariah. Jakarta: Renaisan.

Suswinarno, I. D. (2011). Akad Syariah.

Bandung: Kaifa.

Syarifuddin, A. (2009). Ushul Fiqh.

Ciputat: Logos Wacana Ilmu.

Tim Penulis Dewan Syari'ah Nasional

(DSN) MUI. (2003). Himpunan

Fatwa Dewan Syariah Nasional.

Jakarta: PT. Intermasa. 